\title{
Use of Kinetic and Thermodynamic Parameters for the Prevention of Enzymatic Browning of Edible Yam Dioscorea cayenensis-rotundata cv. "Zrèzrou"
}

\author{
J. Kouamé, S.N. Gnangui, F.M.T. Koné* and L.P. Kouamé \\ Department of Food Science and Technology, University Nangui Abrogoua, \\ 02 BP 801 Abidjan 02, Côte d'Ivoire \\ *Corresponding author
}

\begin{tabular}{|c|c|}
\hline \multicolumn{2}{|r|}{ A B S T R A C T } \\
\hline Keywords & \\
\hline $\begin{array}{l}\text { Yam, Dioscorea } \\
\text { cayenensis-rotundata, } \\
\text { Polyphenol oxidase, } \\
\text { Kinetic and } \\
\text { Thermodynamic } \\
\text { analysis, Heat } \\
\text { inactivation, } \\
\text { Inhibition. }\end{array}$ & \multirow{3}{*}{ 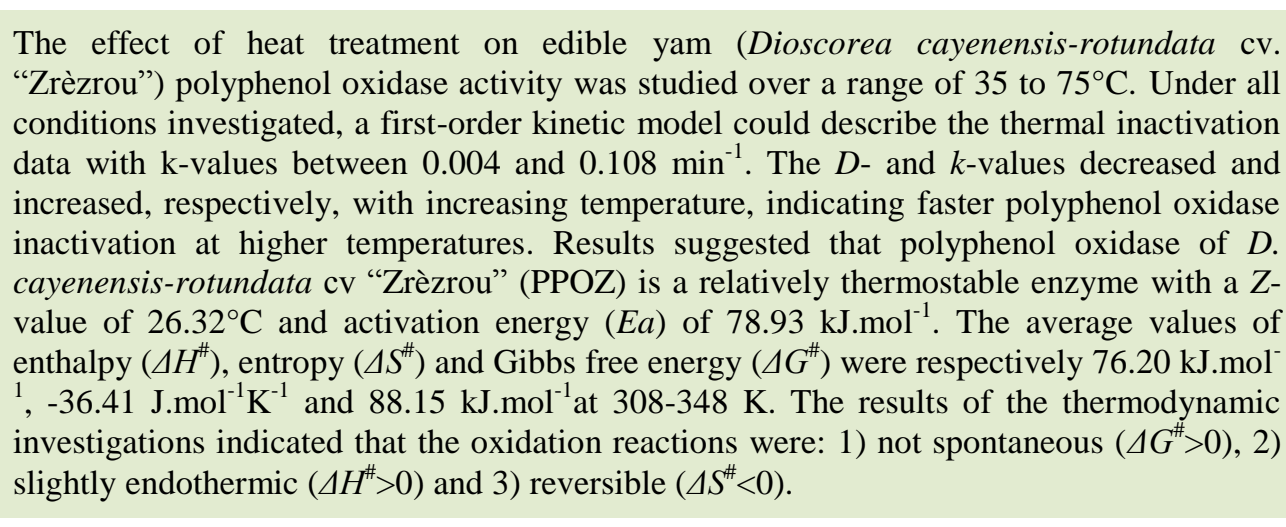 } \\
\hline Article Info & \\
\hline $\begin{array}{l}\text { Accepted: } \\
\text { 28 September } 2017 \\
\text { Available Online: } \\
\text { 10 November } 2017\end{array}$ & \\
\hline
\end{tabular}

\section{Introduction}

Yams belong to the genus Dioscorea in the family of Dioscoreacea and are monocotyledonous. They are an important source of carbohydrate for many people of the sub-Sahara region, especially in the yam zone of West Africa (Akissoe et al., 2003). In Côted'Ivoire, due to traditions, yam plays a vital role in feeding the population, despite the strong expansion of cassava, bananas and rice(Amani et al., 2008; Kone et al., 2016). Its popular taste and high nutritional value and dietary allow him to enjoy a picture prestigious product, and support competition from other starchy foods such as cereals and cassava. Indeed, yam tubers, rich in starch are consumed almost in tropical regions in different forms (Amani et al., 2008; Dabonne et al., 2010; Kone et al., 2016). Despite its strong contribution to the nutritional wellbeing and economic of populations, yam tubers are perishable and seasonal products. The loss is however higher in early tubers. Losses are due to rots caused by bacteria, fungi, damage during harvesting, transport and the germination, but also to oxidation reactions catalyzed endogenous phenolic compounds by polyphenol (Treche, 1989). When they were pelled, the pulp colour 
ranges from creamy white to dark brown. This browning process leads to a change in flavour and a reduction in nutritional quality, especially ascorbic acid (Golan-Goldhirsh and Whitaker, 1984). The discoloration phenomenon has long been studied on fresh tubers and has mainly been associated with enzymatic browning, due to the action of polyphenol oxidase, peroxidase and to the production of polyphenols and derived products (Adams and Brown, 2007).

Polyphenoloxidase (PPO) is present in most fruits and vegetables. It is a copper containing oxidoreductase which catalyzes two distinct reactions involving phenolic compounds and molecular oxygen, namely a) the $o$ hydroxylation of monophenols to $o$-diphenols, or cresolase activity (monophenol, monooxigenase, EC 1.14.18.1); and b) the subsequent oxidation of $o$-diphenols to $O$ quinones, or catecholase activity (diphenol oxygen oxidoreductase, EC 1.10.3.1). These quinones are highly reactive, electrophilic molecules that covalently modify one crosslink to a variety of cellular constituents (Abbattista Gentile et al., 1988).

The main step in enzymatic browning is the oxidation of phenolic compounds by PPO in the presence of oxygen to corresponding quinone intermediates that polymerize to form undesirable pigments. Browning reactions in tubers such as fresh fruits, juices, and wines during processing and storage are well known and are an economic problem for producers and consumers. Several routes are planned to delay or block this physiological phenomenon (Cheriot, 2007). Currently, in addition to traditional technological processes (bleaching, freezing) or innovative (pulsed electric field, controlled atmosphere packaging), synthetic antioxidants are used to prevent these alterations. Natural additives, such as vitamin $\mathrm{C}$, citric acid is also used against enzymatic browning, but the quantities used to effectively prevent the oxidation and the cost of these two compounds are expensive treatments for products low value added(Cheriot, 2007). This is why many current research aims to discover or invent ways to prevent these oxidations, which are effective, easy to implement, requiring little investment and inexpensive to use while being devoid of adverse effects on the organoleptic properties of food products.

Thus, the search for better methods of struggle against enzymatic browning through the mastery and control of PPO activity in foods today still arouses considerable interest in researchers.Several methods were used to prevent enzymatic browning but inactivation of PPO by thermal processing is considered the most effective method to inhibit enzymatic browning(Weemaes et al., 1998). Therefore, the aim of this study is to prevent enzymatic browning by kinetic and thermodynamic parameters of polyphenoloxidase (PPOZ) from edible yam Dioscorea cayenensis-rotundata cv "Zrèzrou".

\section{Materials and Methods}

\section{Enzyme source}

Mature tubers of Dioscorea cayenensis rotundata cv "Zrèzrou" were obtained from the Biological Garden University of Nangui Abrogoua (Abidjan, Côte d'Ivoire) and stored at $-20^{\circ} \mathrm{C}$ until used. The PPOZ substrate dopamine was procured from Sigma Chemical Co. (St. Louis, Mo., U.S.A.). All other chemicals and reagents were of analytical grade.

\section{Preparation of polyphenol oxidase}

Freshly peeled tubers $(150 \mathrm{~g})$ were homogenized in $300 \mathrm{ml}$ of cold $\mathrm{NaCl} 0.9 \%$ (w/v) for $10 \mathrm{~min}$. The resulting homogenate 
was centrifuged at $20000 \mathrm{~g}$ for $10 \mathrm{~min}$ at $4^{\circ} \mathrm{C}$. The supernatant represented the crude extract. This enzymatic solution $(20 \mathrm{ml})$ was loaded onto aDEAE-Sepharose CL-6B gel $(2.4 \mathrm{~cm} \mathrm{x}$ $6.5 \mathrm{~cm}$ ) that had been equilibrated previously with $100 \mathrm{mM}$ phosphate buffer $\mathrm{pH}$ 6.0. The unbound proteins were removed from the column by washing with two column volumes of the same buffer $\mathrm{pH}$ 6.0. Proteins were eluted using a stepwise gradient with $0,0.3$, 0.5 and $1 \mathrm{M} \mathrm{NaCl}$ in $100 \mathrm{mM}$ phosphate buffer $\mathrm{pH}$ 6.0. Fractions $(3 \mathrm{ml}$ each) were collected at a flow rate of $180 \mathrm{ml} / \mathrm{h}$ and assayed for enzyme activity. The active fractions were pooled and saturated overnight by $80 \%$ ammonium sulphate in a cold room. The precipitated pellet was then separated by centrifugation at $20000 \mathrm{~g}$ for $30 \mathrm{~min}$ and dissolved in $1 \mathrm{ml}$ of $100 \mathrm{mM}$ phosphate buffer $\mathrm{pH} 6.0$.

The enzyme solution was loaded directly into a Sephacryl S-100 HR (1.6 cm x $64 \mathrm{~cm})$, which was pre-equilibrated with the same buffer $\mathrm{pH}$ 6.0. Proteins were eluted at a flow rate of $20 \mathrm{ml} / \mathrm{h}$ using $100 \mathrm{mM}$ phosphate buffer $\mathrm{pH}$ 6.0. Fractions $(1 \mathrm{ml})$ were collected and active fractions were pooled together. The pooled fraction from the previous step was saturated to a final concentration of $1.7 \mathrm{M}$ ammonium sulphate and applied on a PhenylSepharose CL-6B column $(1.4 \mathrm{~cm}$ x $7.5 \mathrm{~cm})$ previously equilibrated with $100 \mathrm{mM}$ phosphate buffer $\mathrm{pH} 6.0$ containing $1.7 \mathrm{M}$ ammonium sulphate.

The column was washed with equilibration buffer and the proteins retained were then eluted using a stepwise gradient with $1.7,1$, 0.7, 0.3 and $0 \mathrm{M}$ ammonium sulphate in 100 $\mathrm{mM}$ phosphate buffer $\mathrm{pH}$ 6.0. Fractions of 1 $\mathrm{ml}$ were collected at a flow rate of $15 \mathrm{ml} / \mathrm{h}$ and active fractions were pooled together. The pooled fraction was dialyzed against $100 \mathrm{mM}$ phosphate buffer $\mathrm{pH} 6.0$ overnight in a cold room.

\section{Enzyme assay}

The PPOZ activity was assayed by a spectrophotometric procedure. The increase of absorbance at $480 \mathrm{~nm}$ at $30^{\circ} \mathrm{C}$ was recorded automatically for $10 \mathrm{~min}$. The sample cuvette contained $0.8 \mathrm{ml}$ substrate dopamine $10 \mathrm{mM}$ in $100 \mathrm{mM}$ phosphate buffer $(\mathrm{pH}=6.0)$ and $100 \mu \mathrm{l}$ undiluted enzyme extract. The blank sample contained only $0.8 \mathrm{ml}$ substrate solution in $100 \mathrm{mM}$ phosphate buffer $\mathrm{pH}$ 6.0. Experiments were performed in triplicate, and the results expressed as units (U) of enzymatic activity. One unit of enzymatic activity was defined as an increase in absorbance of 0.001 per min(Bartolo and Birk, 1998).

\section{Protein determination}

Protein was determined according to the method of Lowry et al.,(1951)using bovine serum albumin as standard.

\section{Thermal inactivation}

Thermal inactivation of the enzyme was investigated at $\mathrm{pH} 6.0$ at various constant temperatures from 25 to $75^{\circ} \mathrm{C}$ after exposure to each temperature for a period of 5 to 60 min. Aliquots were withdrawn at intervals and immediately cooled in ice bath, in order to stop heat inactivation.

Experiments were performed in triplicate. The residual enzymatic activity, determined at $30^{\circ} \mathrm{C}$ under the standard test conditions, was expressed as percentage activity of zero-time control of the untreated enzyme.

\section{Kinetic analysis}

The temperature dependence of the reaction rate constant for the studied enzyme served as the basis for fitting to the Arrhenius equation(Arrhenius, 1889): 
$\operatorname{Ln}(A t / A O)=-k t($ Eq.1)

Where, At is the residual enzyme activity at time $\mathrm{t}(\mathrm{min})$, Ao is the initial enzyme activity, $k\left(\mathrm{~min}^{-1}\right)$ is the inactivation rate constant at a given condition. The $k$-values were obtained from the regression line of $L n(A t / A o)$ versus time as slope.

The $D$-value is defined as the time needed, at a constant temperature, to reduce the initial enzyme activity $(A o)$ by $90 \%$. The $D$-values $\left(D_{t}\right)$ were calculated by regression analysis of the lines obtained by plotting the logarithm of the activity expressed as the percentage of initial activity against time. The $D$-values correspond to the reciprocal of the slope of those lines. The decimal reduction time $(D)$ was calculated according to Stumbo(1973) as:

$D=2.303 / k($ Eq.2)

The $Z$-value $\left({ }^{\circ} \mathrm{C}\right)$ is the temperature increase needed to induce a 10 -fold reduction in $D$ value(Stumbo, 1973). This $Z$-value follows the equation:

$\log (D 1 / D 2)=(T 2-T 1) / Z(E q .3)$

Where, $T 1$ and $T 2$ are the lower and higher temperatures in ${ }^{\circ} \mathrm{C}$ or $\mathrm{K}$. Then,D1 and $D 2$ are $D$-values at the lower and higher temperatures in min, respectively. The $Z$-values were determined from the linear regression of $\log (D)$ and temperature $(\mathrm{T})$.

\section{Thermodynamic parameters}

The treatment temperature and the rate constant in a denaturation process are related according to the Arrhenius equation:

$k=A e^{(-E a / R T)}(\mathrm{Eq} .4)$

Where, $k$ is the reaction rate constant value, $A$ the Arrhenius constant, $E a\left(\mathrm{~kJ}^{\mathrm{mol}}{ }^{-1}\right)$ the

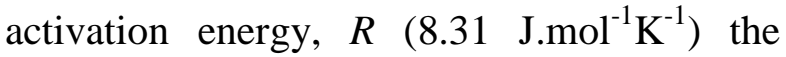
universal gas constant and $T(\mathrm{~K})$ the absolute temperature.

Equation 4 (Eq.4) can be transformed to:

$\ln k=\ln A-(E a / R T)($ Eq.5)

When $\ln k$ is plotted versus the reciprocal of the absolute temperature, a linear relationship should be observed in the temperature range studied. The slope of the line obtained permitted to calculate the Eaand the ordinate intercept corresponds to $\ln A$ (Dogan et al., 2002). The values of the activation energy $(E a)$ and Arrhenius constant $(A)$ allowed the determination of different thermodynamic parameters such as variations in enthalpy $\left(\Delta H^{\#}\right)$, entropy $\left(\Delta S^{\#}\right)$ and Gibbs free energy $\left(\Delta G^{\#}\right)$ according to the following expressions:

$\Delta H^{\#}=E a-R T$ (Eq.6)

$\Delta S^{\#}=R\left(\ln A-\ln K_{B} / h_{P}-\ln T\right)($ Eq.7)

$\Delta G^{\#}=\Delta H^{\#}-T \Delta S^{\#}(\mathrm{Eq} .8)$

Where, $K_{B} \quad\left(1.38 \times 10^{-23} \quad \mathrm{~J}^{-\mathrm{K}^{-1}}\right)$ is the Boltzmann's constant, $h_{P}$ the Planck's constant $\left(6.626 \times 10^{-34} \mathrm{~J} . \mathrm{s}\right)$ and $T$ the absolute temperature.

\section{Statistical analyses}

All determinations reported in this study were carried out in triplicate. Results were expressed as means \pm standard deviation.

\section{Results and Discussion}

\section{Influence of temperature and time of pre- incubation}

The profile of thermal stability of polyphenoloxidase from edible yam Dioscorea cayenensis-rotundata cv "Zrèzrou" (PPOZ) is showed in Table 1. For temperatures between $35-75^{\circ} \mathrm{C}$, the 
denaturation of the enzyme occurred after 5 min of pre-incubation in the phosphate buffer $100 \mathrm{mM}$ (pH 6.0). The enzyme inactivation is total from $75^{\circ} \mathrm{C}$ after $25 \mathrm{~min}$ of preincubation. The logarithmic linear relationship between PPOZ activity and treatment time for the temperature range of $35-75^{\circ} \mathrm{C}$ (Fig. 1) followed first-order kinetics and was consistent with the relationships found in earlier studies on fruits and vegetables (Dimick et al., 1951; Mc Cord and Kilara, 1983; Dogan et al., 2005; Ditchfield et al., 2006; Rapeanu et al., 2006; Gnangui et al., 2009). This result suggests that PPOZ is the only enzyme which is present in the reaction mixture of oxidizing the dopamine in the presence of molecular oxygen environment. This also reflected the only phase obtained for graphs $\ln (A t / A o)$ based on pre-incubation time. Indeed, the presence of isoforms usually results in a curve with several phases. The increasing temperature from 30 to $75^{\circ} \mathrm{C}$ results in a decrease of enzyme activities.

\section{Rate constants of the reaction and half-life}

The rate constants of the first order ( $k$-value) of the catalyzed reaction of PPOZ during the thermal inactivation and the half-life are shown in Table 2 . The half-life $\left(t_{1 / 2}\right)$ of the catalyzed reactions by the $\mathrm{PPOZ}$ decrease as the temperature increases. At $60^{\circ} \mathrm{C}$, it is equal to $27.72 \mathrm{~min}$. Therefore the half-life decreases with increasing temperature. The rate constants of the enzyme protein increase with the temperature of pre-incubation. This observation reflects that this biocatalyst is sensitive to temperature change.

\section{The $D$-, $Z$ - and $E a$-values of the polyphenol oxidase during thermal inactivation}

The effects of temperature on $D$-, $Z$ - and $E a$ values for thermal inactivation of purified PPOZ are presented in Table 3. As expected the decimal reduction time decreases with temperature increase. At $75^{\circ} \mathrm{C}$ the $D$-value is almost $12.72 \mathrm{~min}$. The $D$-values obtained at pre-incubation temperatures of 35 to $75^{\circ} \mathrm{C}$, decreased linearlyfrom 767.67 to $8.63 \mathrm{~min}$ (Table 3, Fig. 2). The $\log (D)$ representation according to the pre-incubation temperature of PPOZ was described by an affine line. The equation of this representation is: $\log (D)=-$ $0.038 T+14.66(\mathrm{R}=0.965)$. It was determined that the $Z$-values are $26.32{ }^{\circ} \mathrm{C}$. The graph of lnk as a function of the inverse of the temperature in $k$ also gave an affine negative slope (Fig. 3). The kinetic is described by the equation: $k=\ln [-9498.2 x(1 / T)+25.173]\left(\mathrm{R}^{2}\right.$ $=0.965)$ where $T$ is the absolute temperature. The activation energy $(E a)$ of the polyphenol oxidase is positive and is $78.93 \mathrm{~kJ} . \mathrm{mol}^{-1}$. The kinetic parameters $D, Z$ and $E a$ permit to know the degree of enzyme stability to temperature variations. It is well to define these terms to better understand their involvement in the process of destabilization of the enzyme. The decimal reduction time $(D)$ reflects the time required to reduce the enzyme activity by $90 \%$. A high $D$-value indicates that the enzyme is thermostable. The thermal resistance $(Z)$ is the elevation of the temperature necessary to reduce the $D$-value of $90 \%$ and the activation energy $(E a)$ is the amount of energy required to keep the enzyme-substrate complex its activated form. The $Z$-value $\left(25^{\circ} \mathrm{C}\right)$ obtained for PPOZ is lower than that obtained by Gnangui et al.,(2009) with PPO of yam tuber $D$. cayenensis-rotundatacv "Longbo". This result shows that PPO of this cultivar is more thermostable than that of the cultivar "Zrèzrou" from D. cayenensis-rotundata. According to Barrett et al.,(1999), low Zvalues $\left(3.1-20{ }^{\circ} \mathrm{C}\right)$ indicate a high sensitivity to heat, so that high $Z$-values indicate a high resistance of the enzyme against heat during heat treatments. But PPOZ is more resistant against heat than that reported by VamosVigyazo(1981) on fruits and vegetables 
whose values are between 8.5 and $10.1^{\circ} \mathrm{C}$.Results obtained for the activation energy showed that PPOZ $\left(83.96 \mathrm{~kJ}^{\mathrm{mol}} \mathrm{m}^{-1}\right)$ is more sensitive to heat than PPO from wild rice $\left(23.3 \mathrm{~kJ}^{\mathrm{mol}}{ }^{-1}\right.$, Aguilera et al., 1987),plantain (18 kJ.mol ${ }^{-1}$, Ngalani et al., 1993)and yam D.cayenensis-rotundata cv "Longbo" (67.67 kJ.mol ${ }^{-1}$, Gnangui et al., 2009). However, it is less sensitive than PPO from banana $\left(413 \mathrm{~kJ}_{\mathrm{mol}}{ }^{-1}\right.$, Dimick et al., 1951) and apple (241-323 $\mathrm{kJ}^{\mathrm{mol}}{ }^{-1}$, Yemenicioglu et al., 1999).

Fig.1 Thermal inactivation curves of polyphenol oxidase from edible yam (D. cayenensisrotundata cv "Zrèzrou") in sodium phosphate buffer ( $\mathrm{pH} 6.0)$ in temperature range $35-75^{\circ} \mathrm{C}$. $A_{0}$ is the initial enzymatic activity and $A t$ the activity at each holding time
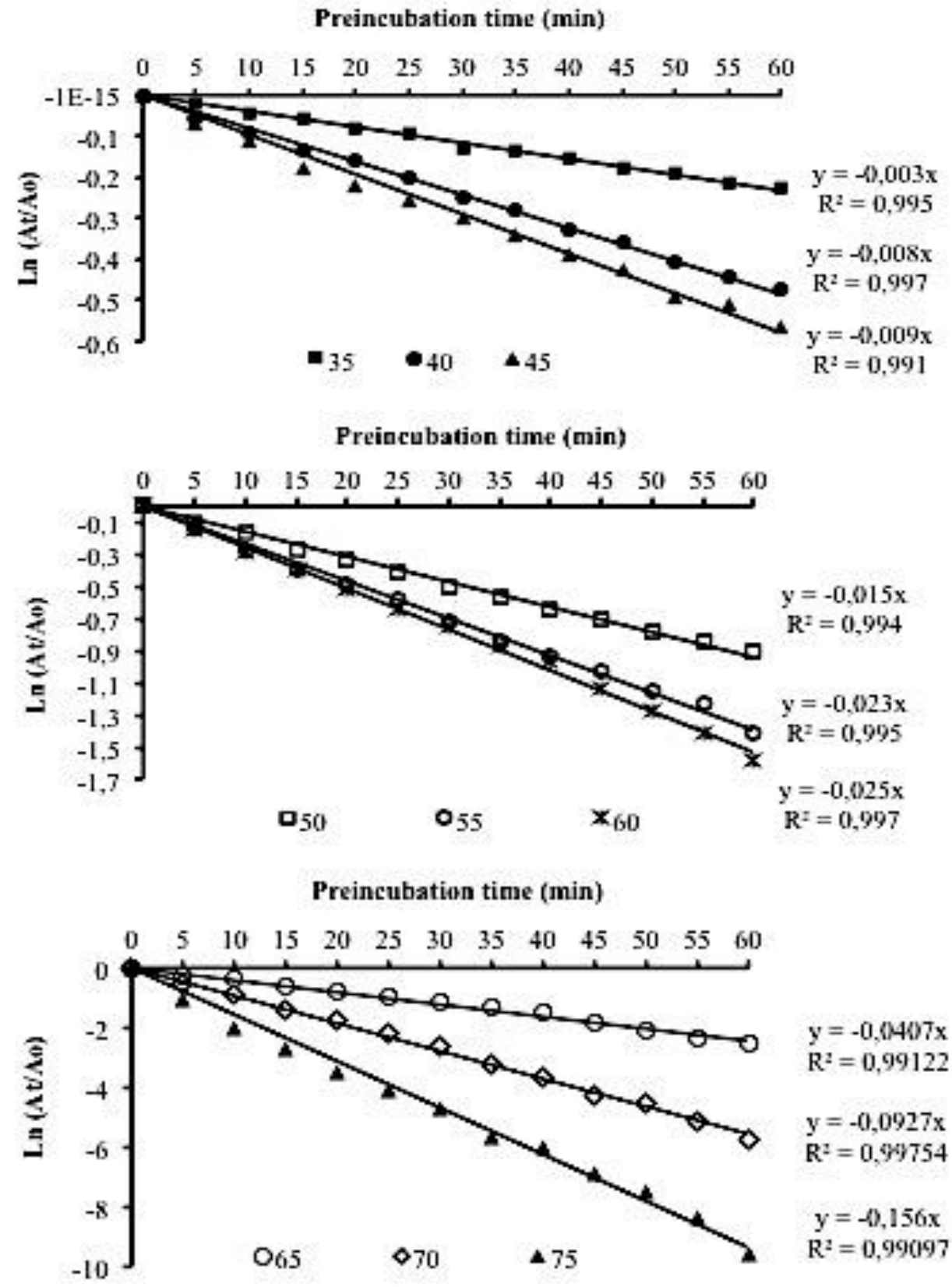
Fig.2 Effect of temperature on $D$-values for inactivation of edible yam (D. cayenensis-rotundata cv "Zrèzrou") polyphenol oxidase activity

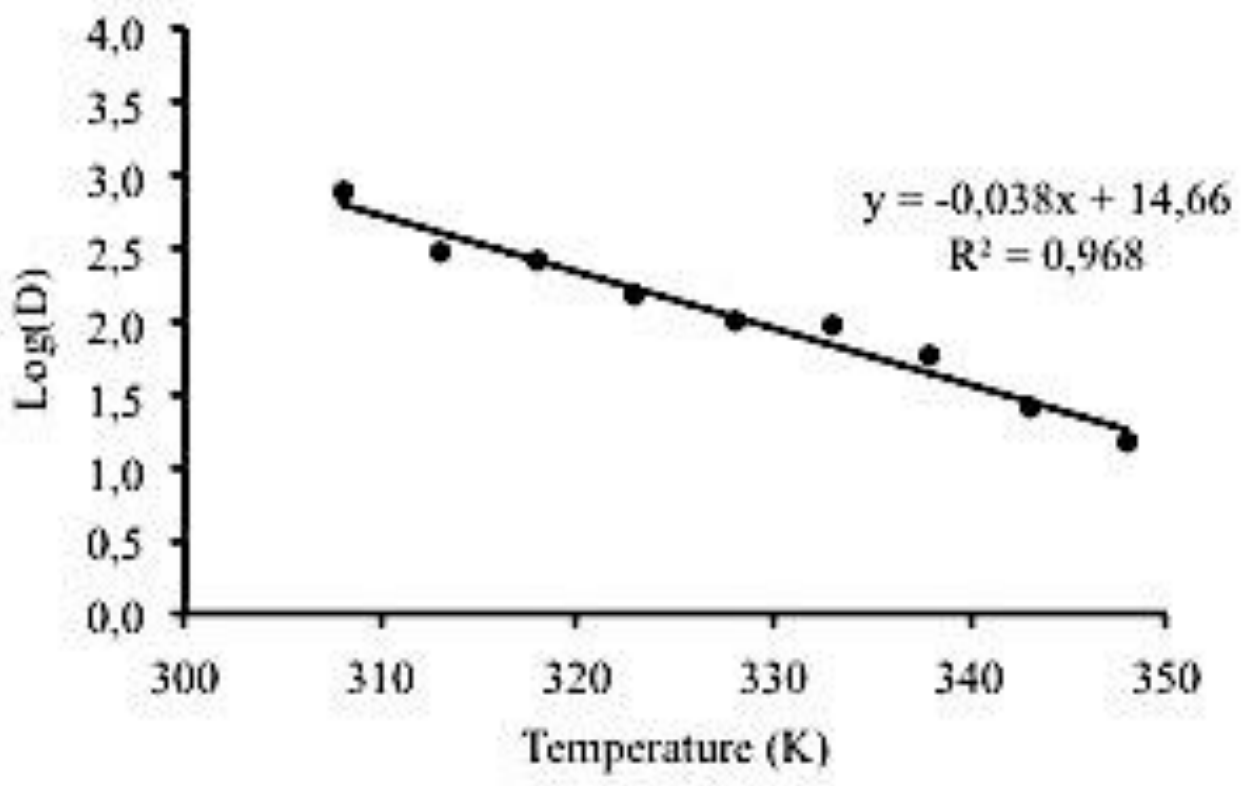

Fig.3 Temperature dependence of inactivation rate constant for thermal inactivation of edible yam (D. cayenensis-rotundata cv "Zrèzrou") polyphenol oxidase. 1/T represents the reciprocal of the absolute temperature

\section{$1 / \mathrm{T}\left(\mathrm{K}^{-1}\right)$}

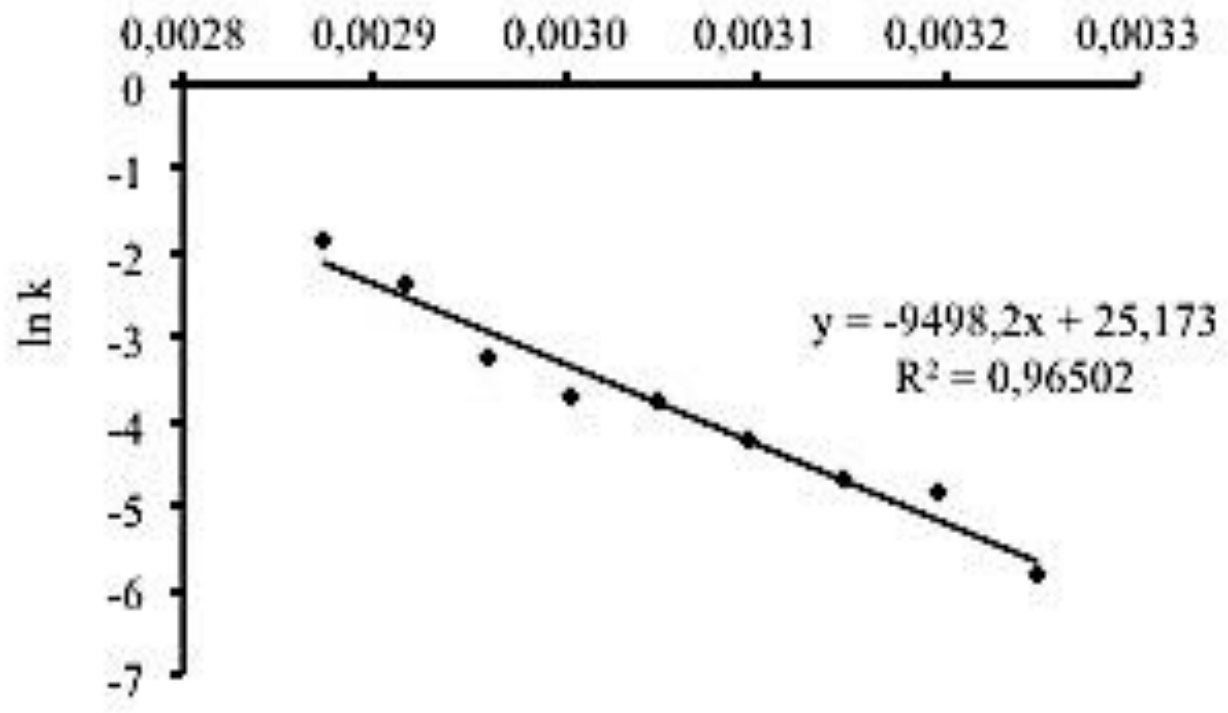




\section{Int.J.Curr.Microbiol.App.Sci (2017) 6(11): 4176-4187}

Table.1 Effect of treatment temperature and time on the polyphenol oxidase inactivation from edible yam (D. cayenensis-rotundata cv "Zrèzrou")

\begin{tabular}{|c|c|c|c|c|c|c|c|c|c|c|c|c|}
\hline \multirow{2}{*}{$\begin{array}{c}\text { Temperature } \\
\left({ }^{\circ} \mathrm{C}\right)\end{array}$} & \multicolumn{12}{|c|}{ Relative activity (\%) at each treatment time (min) } \\
\hline & 5 & 10 & 15 & 20 & 25 & 30 & 35 & 40 & 45 & 50 & 55 & 60 \\
\hline \multirow[t]{2}{*}{35} & 97.73 & 95.43 & 94.41 & 92.10 & 91.28 & 87.99 & 87.19 & 85.56 & 83.86 & 82.56 & 80.82 & 79.61 \\
\hline & \pm 0.002 & \pm 0.001 & \pm 0.002 & \pm 0.002 & \pm 0.003 & \pm 0.001 & \pm 0.003 & \pm 0.001 & \pm 0.001 & \pm 0.003 & \pm 0.001 & \pm 0.003 \\
\hline \multirow[t]{2}{*}{40} & 94.47 & 91.30 & 87.46 & 85.21 & 81.79 & 77.72 & 75.50 & 72.18 & 69.70 & 66.34 & 64.15 & 62.09 \\
\hline & \pm 0.003 & \pm 0.002 & \pm 0.002 & \pm 0.002 & \pm 0.002 & \pm 0.002 & \pm 0.002 & \pm 0.002 & \pm 0.002 & \pm 0.002 & \pm 0.003 & \pm 0.002 \\
\hline \multirow[t]{2}{*}{45} & 93.52 & 89.67 & 83.86 & 80.36 & 77.34 & 74.20 & 70.96 & 67.64 & 65.22 & 61.26 & 60.05 & 56.89 \\
\hline & \pm 0.003 & \pm 0.002 & \pm 0.001 & \pm 0.003 & \pm 0.001 & \pm 0.003 & \pm 0.003 & \pm 0.001 & \pm 0.001 & \pm 0.003 & \pm 0.002 & \pm 0.001 \\
\hline \multirow[t]{2}{*}{50} & 90.39 & 84.74 & 76.72 & 71.46 & 66.38 & 60.23 & 57.06 & 52.83 & 49.25 & 45.83 & 42.74 & 40.78 \\
\hline & \pm 0.001 & \pm 0.002 & \pm 0.002 & \pm 0.001 & \pm 0.002 & \pm 0.001 & \pm 0.001 & \pm 0.001 & \pm 0.002 & \pm 0.002 & \pm 0.001 & \pm 0.002 \\
\hline \multirow[t]{2}{*}{55} & 87.41 & 75.69 & 67.64 & 61.82 & 56.05 & 48.82 & 43.04 & 39.46 & 36.06 & 31.63 & 29.23 & 24.17 \\
\hline & \pm 0.002 & \pm 0.003 & \pm 0.003 & \pm 0.002 & \pm 0.002 & \pm 0.001 & \pm 0.002 & \pm 0.001 & \pm 0.002 & \pm 0.002 & \pm 0.002 & \pm 0.003 \\
\hline \multirow[t]{2}{*}{60} & 85.83 & 75.20 & 67.71 & 59.67 & 52.62 & 46.90 & 41.77 & 37.95 & 32.30 & 28.06 & 24.22 & 20.47 \\
\hline & \pm 0.001 & \pm 0.001 & \pm 0.002 & \pm 0.003 & \pm 0.003 & \pm 0.002 & \pm 0.003 & \pm 0.002 & \pm 0.002 & \pm 0.003 & \pm 0.002 & \pm 0.001 \\
\hline \multirow[t]{2}{*}{65} & 77.03 & 67.98 & 53.96 & 46.63 & 39.65 & 31.44 & 26.47 & 21.98 & 16.69 & 12.14 & 9.33 & 8.17 \\
\hline & \pm 0.003 & \pm 0.001 & \pm 0.003 & \pm 0.001 & \pm 0.002 & \pm 0.001 & \pm 0.001 & \pm 0.002 & \pm 0.002 & \pm 0.001 & \pm 0.003 & \pm 0.002 \\
\hline \multirow[t]{2}{*}{70} & 60.59 & 40.62 & 25.13 & 17.20 & 10.94 & 7.17 & 3.95 & 2.47 & 1.37 & 1.09 & 0.60 & 0.33 \\
\hline & \pm 0.002 & \pm 0.003 & \pm 0.002 & \pm 0.002 & \pm 0.003 & \pm 0.001 & \pm 0.001 & \pm 0.002 & \pm 0.001 & \pm 0.001 & \pm 0.002 & \pm 0.002 \\
\hline \multirow[t]{2}{*}{75} & 34.23 & 13.53 & 6.72 & 2.99 & 1.61 & 0.89 & 0.36 & 0.25 & 0.10 & 0.06 & 0.02 & 0.01 \\
\hline & \pm 0.001 & \pm 0.001 & \pm 0.002 & \pm 0.001 & \pm 0.002 & \pm 0.003 & \pm 0.001 & \pm 0.001 & \pm 0.003 & \pm 0.001 & \pm 0.002 & \pm 0.001 \\
\hline
\end{tabular}


Table. 2 Reaction rate constant $(k)$ and half-life $\left(\mathrm{t}_{1 / 2}\right)$ for heat inactivation of polyphenol oxidase from edible yam (D. cayenensis-rotundata cv "Zrèzrou") between 35 to $75^{\circ} \mathrm{C}$

\begin{tabular}{cccc}
\hline Temperature $\left({ }^{\circ} \mathrm{C}\right)$ & $k$-value $\left(\mathrm{min}^{-1}\right)$ & $\mathrm{t}_{1 / 2}(\mathrm{~min})$ & $\mathrm{R}^{2}$ \\
\hline 35 & $0.003 \pm 0.001$ & $231.00 \pm 18.230$ & $0.995 \pm 0.002$ \\
40 & $0.008 \pm 0.001$ & $86.63 \pm 11.030$ & $0.997 \pm 0.001$ \\
45 & $0.009 \pm 0.002$ & $77.00 \pm 18.150$ & $0.991 \pm 0.003$ \\
50 & $0.015 \pm 0.001$ & $46.20 \pm 3.100$ & $0.994 \pm 0.002$ \\
55 & $0.023 \pm 0.003$ & $30.13 \pm 4.010$ & $0.995 \pm 0.002$ \\
60 & $0.025 \pm 0.001$ & $27.72 \pm 1.110$ & $0.997 \pm 0.003$ \\
65 & $0.040 \pm 0.00$ & $17.33 \pm 0.001$ & $0.991 \pm 0.002$ \\
70 & $0.092 \pm 0.003$ & $7.53 \pm 0.246$ & $0.997 \pm 0.002$ \\
75 & $0.181 \pm 0.001$ & $4.44 \pm 0.030$ & $0.994 \pm 0.001$ \\
\hline
\end{tabular}

Table.3 $D$-, $Z$ - and $E a$-values for thermal inactivation of polyphenol oxidase from edible yam (D. cayenensis-rotundata cv "Zrèzrou") in sodium phosphate buffer (pH 6.0) in the temperature range $35-75^{\circ} \mathrm{C}$

\begin{tabular}{cc}
\hline Kinetic parameters & Values \\
\hline$D$-values (min) & $767.67 \pm 293.16$ \\
$\mathrm{D}_{35}$ & $287.88 \pm 36.65$ \\
$\mathrm{D}_{40}$ & $255.89 \pm 60.31$ \\
$\mathrm{D}_{45}$ & $153.53 \pm 10.29$ \\
$\mathrm{D}_{50}$ & $100.13 \pm 13.32$ \\
$\mathrm{D}_{55}$ & $92.12 \pm 3,69$ \\
$\mathrm{D}_{60}$ & $57.58 \pm 0.00$ \\
$\mathrm{D}_{65}$ & $25.03 \pm 0.82$ \\
$\mathrm{D}_{70}$ & $14.76 \pm 0.09$ \\
$\mathrm{D}_{75}$ & $26.32 \pm 1.03$ \\
\hline$Z$-value $\left({ }^{\circ} \mathrm{C}\right)$ & $78.93 \pm 3.78$
\end{tabular}

$D$-, Z- and $E a$ were respectively the decimal reduction time, the constant thermal resistance and the activation energy of polyphenol oxidase

Table.4 Thermodynamic parameters for edible yam (D. cayenensis-rotundata cv "Zrèzrou") polyphenol oxidase under heat treatment between 35 to $75^{\circ} \mathrm{C}$ (assuming a 1st-order kinetic model)

\begin{tabular}{cccc}
\hline Temperature & \multicolumn{3}{c}{ Thermodynamic parameters } \\
\cline { 2 - 4 }$\left({ }^{\circ} \mathrm{C}\right)$ & $\Delta H^{\#}\left(\mathrm{~kJ}^{\mathrm{mol}}{ }^{-1}\right)$ & $\Delta S^{\#}\left(\mathrm{~J} \cdot \mathrm{mol}^{-1} \cdot \mathrm{K}^{-1}\right)$ & $\Delta G^{\#}\left(\mathrm{~kJ}^{\mathrm{I}} \mathrm{mol}{ }^{-1}\right)$ \\
\hline 35 & $76.37 \pm 6.66$ & $-35.90 \pm 10.94$ & $87.42 \pm 3.78$ \\
40 & $76.33 \pm 6.81$ & $-36.03 \pm 11.05$ & $87.60 \pm 2.52$ \\
45 & $76.29 \pm 6.97$ & $-36.16 \pm 10.88$ & $87,78 \pm 3.12$ \\
50 & $76.24 \pm 7.12$ & $-36.29 \pm 11.12$ & $87.97 \pm 4.02$ \\
55 & $76.20 \pm 7.27$ & $-36.42 \pm 11.02$ & $88.15 \pm 3.78$ \\
60 & $76.16 \pm 7.42$ & $-36.54 \pm 10.99$ & $88.33 \pm 3.81$ \\
65 & $76.12 \pm 7.58$ & $-36.67 \pm 11.08$ & $88,51 \pm 3.69$ \\
70 & $76.08 \pm 7.73$ & $-36.79 \pm 11.21$ & $88.70 \pm 2.95$ \\
75 & $76.04 \pm 7.89$ & $-36.91 \pm 11.33$ & $88.88 \pm 3.28$ \\
\hline Mean & $76.20 \pm 7.27$ & $-36.41 \pm 11.06$ & $88.15 \pm 3.44$
\end{tabular}

$\Delta H^{\#}, \triangle S^{\#}$ and $\Delta G^{\#}$ were respectively variations in enthalpy, entropy and Gibbs free energy 
Thermodynamic analysis of thermal inactivation of polyphenoloxidase

Enzymes become inactive at temperatures above a critical level due to unfolding of the molecules (Lapanje, 1978). This process is usually reversible for most enzymes but prolonged heating results in irreversible loss of catalytic activity involving destruction of various covalent and no covalent interactions (Ghosh and Nanda, 1993).

Thermodynamic values of variation in enthalpy $\left(\Delta H^{\#}\right)$, entropy $\left(\Delta S^{\#}\right)$ and Gibbs free energy $\left(\Delta G^{\#}\right)$ of PPOZ from edible yam calculated at different temperatures are shown in Table 4. At temperatures range from 35 to $75^{\circ} \mathrm{C}$, the average values of $\Delta H^{\#}, \Delta S^{\#}$ and $\Delta G^{\#}$ were respectively $76.20, \quad-36.41$ and $88.15 \mathrm{~kJ} \cdot \mathrm{mol}^{-1}$.The high enthalpy $\left(\Delta H^{\#}\right)$ change obtained at these different temperaturesfrom edible yam $D$. cayenensisrotundata $\mathrm{cv}$ "Zrèzrou" indicates that $\mathrm{PPOZ}$ undergoes a significant conformational change in order to find in its activated during heat treatment and high amount of energy was required to initiate denaturation, probably due to the molecular conformation of polyphenol oxidase(Marin et al., 2003). Positive values of $\Delta H^{\#}$ indicate the endothermic nature of the oxidation reaction.

According to Anema and Mckenna(1996), the negative values found for entropy $\left(\Delta S^{\#}\right)$ indicates that there are significant processes of aggregation. Indeed $\Delta S^{\#}$ is a physical parameter related to the concentration of the reagents, to the steric hindrance and to the orientation of functional groups. It can be interpreted as measuring the degree of disorder of a system at a microscopic level. Thus most of the system is high $\Delta S^{\#}$ least these elements are ordered, linked together, to produce effects and the higher the proportion of energy used to obtain a work where high values of free energies.
Low $\Delta S^{\#}$ values of PPOZ obtained reflect a low state of disorder during the transition phase following the thermal inactivation, which naturally leads to reduced the $\Delta H^{\#}$ values.

\section{Acknowledgements}

The research was carried out with the support of the Université Nangui Abrogoua, (Abidjan, Côte d'Ivoire). The author is grateful to Professor Kouamé Lucien Patrice (Université Nangui Abrogoua, Côte d'Ivoire, Laboratoire de Biochimie et de Bioprocédé de l'Unité de Formation et de Recherche en Sciences et Technologies des Aliments) for assistance.

\section{References}

Abbattista Gentile, I., Ferraris, L., and Matta, A. 1988. Variations of phenoloxidase activities as a consequence of stresses that induce resistance to Fusarium wilt of tomato. J. Phytopathol. 122(1): 4553.

Adams, J. B., and Brown, H. M. 2007. Discoloration in raw and processed Fruits and vegetables. Crit. Rev. Food Sci. Nutr. 47(3): 319-333.

Aguilera, J. M., Oppermann, K., and Sanchez, F. 1987. Kinetics of browning of sultana grapes. J. Food Sci. 52(4): 990-993.

Akissoe, N., Hounhouigan, J., Mestres, C., and Nago, M. 2003. How blanching and drying affect the colour and functional characteristics of yam (Dioscorea cayenensis-rotundata) flour. Food Chem. 82(2): 257-264.

Amani, N. G., Aka, K. G., N'dri, Y. D., Degbeu, K. C., and Sako, A. 2008. Evolution of functional properties of precocious yam starch (Dioscorea cayenensis-rotundata) during tuberization. Int. J. Biol. Chem. Sci. 2(3): 324-330. 
Anema, S. G., and McKenna, A. B. 1996. Reaction kinetics of thermal denaturation of whey proteins in heated reconstituted whole milk. J. Agric. Food Chem.44(2): 422-428.

Arrhenius, S. 1889. Über die Reaktionsgeschwindigkeit bei der Inversion von Rohrzucker durch Säuren. Z. Phys. Chem. 4(1): 226-248.

Barrett, N. E., Gryison, A. S., and Lewis, M. J. 1999. Contribution of the lactoperoxidase system to the keeping quality of pasteurized milk. J. Dairy Res. 66(1): 73-80.

Bartolo, I., and Birk, E. O. 1998. Some factors affecting Norway lobster (Nephrops norvegicus) cuticle polyphenol oxidase activity and blackspot development. Int. J. Food Sci. Technol. 33(3): 329-336.

Cheriot, S. 2007. Rôle des produits de la réaction de maillard dans l'inhibition de l'oxydation enzymatique des phénols et des lipides. Ph.D. Thesis, AgroParisTech, Paris, France.

Dabonne, S., Dje, K. M., Tetchi, F. A., and Kouame, L. P. 2010. Change in the starch granules of tuber parts of" Kangba" and" Krenglè"(Dioscorea cayenenesis-rotundata complex) during post-harvest storage. Int. J. Biol. Chem. Sci. 4(5)

Dimick, K. P., Ponting, J. D., and Makower, B. 1951. Heat inactivation of polyphenolase in fruit purees. Food Technol. 6: 237-241.

Ditchfield, C., Tadini, C. C., Machoshvili, I. A., and Penna, T. C. V. 2006. Polyphenol oxidase and peroxidase thermal inactivation kinetics used as indicators for the pasteurization of acidified banana puree (Musa cavendishii, Lamb.). Braz. J. Food Technol. 9: 77-82.

Dogan, M., Arslan, O., and Dogan, S. 2002. Substrate specificity, heat inactivation and inhibition of polyphenol oxidase from different aubergine cultivars. Int. J. Food Sci. Technol. 37(4): 415-423.

Dogan, S., Arslan, O., and Özen, F. 2005. Polyphenol oxidase activity of oregano at different stages. Food Chem. 91(2): 341-345.

Ghosh, M., and Nanda, G. 1993. Thermostability of $\beta$-xylosidase from Aspergillus sydowii MG49. FEBS Lett. 330(3): 275-278.

Gnangui, S. N., Due, E. A., Kouadio, N. J.-P. E., and Kouame, L. P. 2009. Effect of heat treatment on edible yam (Dioscorea cayenensis-rotundata $\mathrm{cv}$ Longbô) polyphenol oxidase activity: kinetic and thermodynamic analysis. $J$. Anim. Plant Sci. 2(3): 128-137.

Golan-Goldhirsh, A., and Whitaker, J. R. 1984. Effect of ascorbic acid, sodium bisulfite, and thiol compounds on mushroom polyphenol oxidase. $J$. Agric. Food Chem. 32(5): 1003-1009.

Kone, D., Kone, F. M. T., Bléi, S. H., Faulet, B. M., Dabonne, S., and Kouame, L. P. 2016. Cooking effects on mineral composition and antinutritional factors of flours from yam "kponan" (Dioscorea cayenensis-rotundata) tubers. Int. J. Biol. Chem. Sci. 10(3): 1250-1261.

Lapanje, S. 1978. Physicochemical aspects of protein denaturation (John Wiley and Sons, Inc: New York).

Lowry, O. H., Rosebrough, N. J., Farr, A. L., and Randall, R. J. 1951. Protein measurement with the folin phenol reagent. J. Biol. Chem. 193(1): 265-275.

Marin, E., Sanchez, L., Perez, M. D., Puyol, P., and Calvo, M. 2003. Effect of heat treatment on bovine lactoperoxidase activity in skim milk: kinetic and thermodynamic analysis. J. Food Sci. 68(1): 89-93.

Mc Cord, J. D., and Kilara, A. 1983. Control of enzymatic browning in processed 
mushrooms (Agaricus bisporus). $J$. Food Sci. 48(5): 1479-1484.

Ngalani, J. A., Signoret, A., and Crouzet, J. 1993. Partial purification and properties of plantain polyphenol oxidase. Food Chem. 48(4): 341-347.

Rapeanu, G., Van Loey, A., Smout, C., and Hendrickx, M. 2006. Thermal and high pressure inactivation kinetics of Victoria grape polyphenol oxidase: From model systems to grape must. $J$. Food Process Eng. 29(3): 269-286.

Stumbo, C. R. 1973. Thermobacteriology in food processing (2nd Edn). Academic Press, New York.

Treche, S. 1989. Potentialités nutritionnelles des ignames (Dioscorea spp) cultivées au Cameroun (Ed. Orstom). Collection études et thèses, Paris.
Vamos-Vigyazo, L. 1981. Polyphenol oxidase and peroxidase in fruits and vegetables. Crit. Rev. Food Sci. Nutr. 15(1): 49127.

Weemaes, C. A., Ludikhuyze, L. R., Van den Broeck, I., Hendrickx, M. E., and Tobback, P. P. 1998. Activity, electrophoretic characteristics and heat inactivation of polyphenoloxidases from apples, avocados, grapes, pears and plums. LWT - Food Sci. Technol. 31(1): 44-49.

Yemenicioglu, A., Özkan, M., and Cemeroglu, B. 1999. Some characteristics of polyphenol oxidase and peroxidase from taro (Colocasia antiquorum). Turk. J. Agric. For. 23(4): 425-430.

\section{How to cite this article:}

Kouamé, J., S.N. Gnangui, F.M.T. Koné and Kouamé, L.P. 2017. Use of Kinetic and Thermodynamic Parameters for the Prevention of Enzymatic Browning of Edible Yam Dioscorea cayenensis-rotundata cv. "Zrèzrou”. Int.J.Curr.Microbiol.App.Sci. 6(11): 41764187. doi: https://doi.org/10.20546/ijcmas.2017.611.489 